\title{
Spreading of Islam without any violence in Central, East and West Africa as a case study
}

\begin{tabular}{|c|c|}
\hline $\begin{array}{l}\text { Authors: } \\
\text { Maniraj Sukda } \\
\text { Ensieh Bagher }\end{array}$ & $e_{1,2}^{1}$ (D) \\
\hline $\begin{array}{l}\text { Affiliations: } \\
{ }^{1} \text { Department } \\
\text { Religion and } \\
\text { Faculty of The } \\
\text { Religion, Univ } \\
\text { Pretoria, Sout }\end{array}$ & $\begin{array}{l}\text { Science of } \\
\text { issiology, } \\
\text { logy and } \\
\text { rsity of } \\
\text { Africa }\end{array}$ \\
\hline $\begin{array}{l}{ }^{2} \text { West Studies } \\
\text { World Departr } \\
\text { Encyclopaedia } \\
\text { Foundation, Is } \\
\text { of Iran, Iran }\end{array}$ & $\begin{array}{l}\text { f Islamic } \\
\text { Ient, } \\
\text { Islamica } \\
\text { amic Republic }\end{array}$ \\
\hline $\begin{array}{l}\text { Research Proj } \\
\text { Registration: } \\
\text { Project Leade } \\
\text { Project Numb }\end{array}$ & $\begin{array}{l}\text { ct } \\
\text { M. Sukdaven } \\
\text { r: } 04616546\end{array}$ \\
\hline $\begin{array}{l}\text { Description: } \\
\text { Dr Bagheri is p } \\
\text { in the research } \\
\text { 'Religion in Dia } \\
\text { directed by Dr } \\
\text { Sukdaven, Dep } \\
\text { Science of Reli } \\
\text { Missiology, Fa } \\
\text { Theology and } \\
\text { University of P }\end{array}$ & $\begin{array}{l}\text { articipating } \\
\text { project, } \\
\text { logue', } \\
\text { Maniraj } \\
\text { artment of } \\
\text { jion and } \\
\text { ulty of } \\
\text { eligion, } \\
\text { etoria. }\end{array}$ \\
\hline $\begin{array}{l}\text { Correspondin } \\
\text { Maniraj Sukda } \\
\text { maniraj.sukda }\end{array}$ & $\begin{array}{l}\text { author: } \\
\text { en, } \\
\text { en@up.ac.za }\end{array}$ \\
\hline $\begin{array}{l}\text { Dates: } \\
\text { Received: } 07 \mathrm{~J} \\
\text { Accepted: } 04 \\
\text { Published: } 04\end{array}$ & $\begin{array}{l}\text { ne } 2018 \\
\text { ct. } 2018 \\
\text { ec. } 2018\end{array}$ \\
\hline $\begin{array}{l}\text { How to cite th } \\
\text { Sukdaven, M. } \\
2018 \text {, 'Spreadi } \\
\text { without any vi } \\
\text { Central, Eastar } \\
\text { as a case study } \\
\text { Teologiese Stu } \\
\text { Theological St } \\
\text { a5136. https:/ } \\
\text { 10.4102/hts.v }\end{array}$ & $\begin{array}{l}\text { s article: } \\
\text { Bagheri, E., } \\
\text { g of Islam } \\
\text { lence in } \\
\text { d West Africa } \\
\text {, HTS } \\
\text { lies/ } \\
\text { dies } 74(3) \\
\text { doi.org/ } \\
4 \text { i3.5136 }\end{array}$ \\
\hline Read online: & \\
\hline 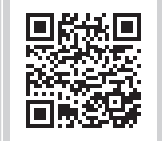 & $\begin{array}{l}\text { Scan this QR } \\
\text { code with your } \\
\text { smart phone or } \\
\text { mobile device } \\
\text { to read online. }\end{array}$ \\
\hline
\end{tabular}

This article studies the violence in the spreading of Islam by conquest and the factors that influenced the development of Islam in Central, East, West and Southeastern Africa. Although the spreading of Islam in these territories had not been done by Islamic conquests, as perpetrated in North Africa and other regions of the Islamic world, the majority of the population in the countries such as Sudan, Chad, Mali, Sierra Leone and Madagascar are Muslims. The results of this article show that the emigrations into these regions had an important role in introducing Islam to the native inhabitants. These emigrations had occurred either freely, through trading by Muslim traders and religious scholars, or forcefully by escaping the political and religious violence perpetrated by Eastern rulers in different areas in Central Africa. In this emigration process, the effect of Islamic scholars, missionaries and Islamic traders together with communication intermediaries among the natives is striking and as the natives became familiar with Islam and Islamic culture, Islam gradually developed after generations of integration between Muslims and native tribes.

\section{Introduction}

Islam, as a final divine religion, appeared in the Arabian Peninsula through Mohammad (Peace be upon him) in the second half of the 7th century AD. He introduced Islam to the different tribes of the Arabian Peninsula. Many tribes accepted Islam and gradually all regions of the Arabian Peninsula accepted it and became Muslims. The Qur'an was the holy book of the Muslims, which had been recited by the prophet Mohammad (Peace be upon him) to his companions (Sahabeh). As a result of the spread of Islam in the Arabian Peninsula, all of its people came under the control of the Islamic government, which he founded in Medina.

It is claimed that Mohammad (Peace be upon him) treated people kindly throughout his life. There are some Hadiths that state that Mohammed (Peace be upon him) recommended that kindness be shown to children and adults and even to animals. There are other moral orders that are expressed in many Hadiths such as Osul Kafi, al Tahdib. In one popular Hadith, it is recorded that Mohammad (Peace be upon him) said, 'I elected to create moral structures among the people' (قالخالا حلاص مجتال تث عب ىنا) (Sa'd 1989:V9, 449).

According to the prophet's narratives, discovered after his death, Islam was spread through the conquests by Islamic Khalifs across the borders of the Arabian Peninsula. In these conquests, they encountered two powerful empires, Persia and Rome, and defeated them, thus occupying their territories and consequently established Islam. These conquests continued from east to west resulting in the development of Islam from the west of China to all of North Africa, even including Andalusia, towards the end of the 8th century. According to the political spreading of Islam by the military forces, the following question was consistently posed: Is Islam a violent religion that developed by force and the blade of a sword as the Islamic Jihad?

Although these conquests were done through military forces and Islamic Jihad in the 7th and 8th century AD, it can be argued that Islam is not such a violent religion because it receives its main instruction, not only about the ontology, which is introduced as Mohkamat in the Qur'an (3:8), but also with regard to anthropological references such as ethnic messages of generosity, love and respect for all people regardless of their different opinions.

In responding to this problem, reference is made to the historic development of Islam in the vast areas of Africa such as East and Southeast Africa, the Horn of Africa and also Central and West Africa, which had not been occupied through conquests such as those that occurred in other Islamic territories but of which the majority of the population in these regions are now Muslims.

Copyright: (C) 2018. The Authors. Licensee: AOSIS. This work is licensed under the Creative Commons Attribution License. 
There were good relationships between Muslims and these native inhabitants to the effect that they gradually grew familiar with Islam and accepted it.

This article introduces some of the main factors that influenced the spread of Islam in the above regions of Africa and explains how Islam penetrated into the hearts of indigenous people who had different customs and traditions.

In this gradual process, there were two main factors that featured prominently in the spreading of Islam in those areas in Africa:

1. emigrations

2. formation of Islamic government without military armies by Muslims and native settlers.

\section{Emigrations}

When the Islamic conquest finished in North Africa in the last era of the Omayyad Khalifs (at the end of the first century anno hegirae $[\mathrm{AH}])$, Muslim armies were busy in Andalusia and began their conquest there, so that they couldn't advance towards the southern regions of Africa. Emigrations were the main cause of spreading of Islam to the southern regions of Africa, especially in the eastern and southeastern areas and also in the Horn of Africa. Arabs were familiar with these regions and travelled there via the Red Sea, before Islam. After that, these emigrations and travels continued especially after the Baqt contract, which Maqrizi (2002) and Bakri (1992) refer to. This agreement was signed between Muslims in North Africa and Christians in Nubia in East Africa and prepared safe travelling among the Muslims, Christians and indigenous people (Sidahmed \& Sidahmed 2005:3). Then the diverse tribes such as Bani Kanz, decedents from Bani Rabie tribe and other groups from Johayne, Rofaah, Hovazen and Mozar tribes from the Saudi Arabian Peninsula travelled to Sudan via the Red Sea, and also to the south of Egypt and merged with Nubian and Baja/Bejjah (Arabic form of Nubia) people and most of them accepted Islam (Ali 1961:127; Holt \& Daly 2000:156-158; Metz 1992:1; Mohy al Din Mohammad 1995:9-10).

The Iranian emigrations from Shiraz to Kilwa on the coast of Somalia in the 11th century by the leadership of Hasan Ibn Ali Ibn Soltan Shirazi and also the emigration of Nobhani's families from Oman were the main emigrations to which some of the researchers refer to according to their sources (Khuli 2011:30, 71; Mohanna 1954:29; Sari al Din 1997:77-78; Ibrahim 2000:38; Yunes 1962:66). These emigrations influenced the spreading of Islam in the Horn of Africa and fostered relationships between Muslims and Somalia's indigenous people and led to the mixing of generations with native inhabitants in Somalia, Eritrea, Ethiopia, Zanzibar and Mozambique resulting in new race groups being created such as Darud and Isak (Hiskett 1994:138).

Also, Muslim tribes such as Zafi-Ramania and Antemoro influenced the development of Islam in Madagascar and Mozambique in Southeast Africa (Bruder 2008:127-128; Page 2001:14; Peek 1991:55). Some groups of travelling tribes from North Africa named Banu Hilal emigrated to the great Sahara in Mauritania in West Africa and had an important role in the spreading of Islam there in the 12th century (Nequla 2002:337).

Muslim immigrants in these areas are divided into three main groups:

1. Fugitives: Fugitives who escaped from the interference and pursuit of governments and wanted to save their lives emigrated to these regions in Africa. The first group were Muslims who emigrated to Hafez (today in Zayla port in Somalia) by the recommendation of the prophet to escape the volatile situation faced by the people of Mecca in $615 \mathrm{AD}$. Upon settling in their new region, they propagated Islam in the Horn of Africa under the protection of the Hafez kings (Mohanna 1954:28; Night 2012:7). In the Umayyad Caliphate, two brothers from the Azad tribe who were the sons of Ebad al Jolandi, the ruler of Oman, escaped with their families to Somalia after they rebelled against the Umayyads. They founded the city of Izab in Somalia (Hafiz 1982:44; Ibrahim 2000:38). Also, some of the Zaidis escaped to Banadir in the north of Somalia when Zayd Ibn Ali, their leader, was killed in the Umayyad era (Asante 2007:177). When the Abbasid Caliphs came, some of the Umayyad families along with some of the Khawaridjs and Alawids escaped from Abbasid to Sudan in the east of Africa and accelerated the development of Islam there (Fituri 1998:122-123; Jamal 2008:216-221; Mas'udi 1970:Vol. 3, 42-43). With the emigration of Arab and Muslim travellers and the integration with indigenous people, African-Arabic races were created.

2. Muslim traders: Apart from the refugees or fugitives emigrating or fleeing to Africa, the first group of Muslims who came to East Africa were Arab traders or Muslim merchants from the Arabian Peninsula. They were familiar with the eastern regions of Africa long before the rise of Islam. They conducted business there, accessing the region via the Red Sea for thousands of years. This business continued after the Islamic conquest of North Africa and Muslim traders travelling to the southern regions of Africa increased. They developed trading stations and expanded their trading relations inland, which also became centres for promulgation of Islam. At these stations, they set up Quranic schools and pupils studied in these schools and as a result grew familiar with Islamic teachings. As a result of Islamic Caliphs having access to the main trading routes in the Mediterranean and the Red Sea, some Islamic commerce centres were built on the coast of Somalia, Ethiopia, Kilwa and Mombasa, thus increasing the number of Muslim immigrant traders to East Africa. The main motivation for traders to travel to the southern regions of Africa was the founding and accessing of the gold mines (Hiskett 1994:139; Night 2012:7; Trimingham 1952:215). Bakri (2002:Vol. 2, 325) explains about emerald mines in Bejjah, which were under the control of Banu Rabia'h Muslim Arab tribes. Muslim traders exchanged their goods for gold and jewellery in those regions. They also built some 
mosques there in order to perform their own worship (Hartman 2004:16-28). These mosques manifested Islam, thus causing the native inhabitants to become acquainted with Islam as they communicated and interacted with Muslim traders. More than from the direction of the Red Sea, Muslim traders travelled to Central Africa from two other directions: one from the banks of the Nile River to Central Africa and the Chad Lake areas and the other from the direction of north to south in the Great Sahara. Trading in gold, iron, ivory, copper and slaves were the main factors that encouraged them to commute. These traders played an important role in establishing social relations with the indigenous people and acquainted them with Islam (Fituri 1998:152-153; Hasan 2003:17; Jamal 2008:216; Metz 1992:4-5; Shater Basili 1972:32, 35).

3. Religious scholars: The central concept of Islam was taught essentially by religious Islamic scholars in these areas. They travelled to these areas individually and introduced Islam to native tribes. They played the main role in converting heathen people of Negroes and Bejjah tribes to Islam. They were in Zavaya and mosques and trained in Shafii jurisprudence, Maliki jurisprudence and Sufism (Fazli 1921:5, 140; Trimingham 1965:100-101). Also, Ibadhi Khawarij scholars helped the development of Islam in West Africa (Nequla 2002:337). The emigrations of religious scholars to the eastern regions and the Horn of Africa increased after the establishment of Islamic cities there and they even built some mosques for women where they taught religious instructions (Khuli 2011:232). Morabit scholars, attributed to Morabit government in North Africa, developed Islam in West Africa during the 12th century (Nequla). They were the main core of Sufism in Africa and they established Zavaya in different parts of Africa and propagated Islam there. The different Sufi sects, such as Qaderiyyah, Tijaniyyah, Fazeliyyah and Shazeliyyah, were created in these areas and these sects had a moderate approach and refrained from violence (Nequla; Khuli).

The presence of travellers alongside the native tribes in Africa caused difficulties causing Muslims to build Islamic towns like Zaila', Harar and Kilwa, separate from the ancient cities of Africa. These cities also served as centres for spreading Islam.

\section{Islamic governments}

The other main factor in influencing native people in Eastern, Central and Western Africa was the formation of Islamic governments. These governments had been formed either by Muslim immigrants in the cities they had built in Harar, Zayla, Adal, Mogadishu and Kilwa or by the tribal chiefs and the kings of native inhabitants who accepted Islam. An example of this is the Kanem Islamic government, which was established near the Chad Lake in Central Africa after the adoption of Islam by May Heum, king of Kanem-Borno. This resulted in Islam being firmly established in these regions. He accepted Islam not by sword or violence but by his acquaintance with Islam via Muslim immigrants and imitating them (Collelo 1988:8-9; Nuri 1985:164; Shater Basili 1972:412). Another example is Ammare Dunqas, the leader of Fonj pagan tribes. After his familiarity with Abd al lab tribe, he converted to Islam and formed the Islamic government in Sennar in North Sudan (Ali 1961:4; Bruce 1790:V4, 458; Fazli 1921:5; Hasan 2003:53). The formation of Islamic governments in western Africa and on the sides of the Senegal River, such as Mali, Songhay, Futa Jalun, Takrur and Salla, and Shiraz's government in Kilwa in the Horn of Africa contributed to the development of Islam in these regions. The people of Takrur became Muslims when their leader named Arjabi accepted Islam (Nequla 2002:338). Also, Sondiata among the Mande tribes and Zakoses among the Songhay tribes created Islamic governments after the adoption of Islam (Bari, Fazel \& Keridiyyah 1971:78-79; Nequla 2002:338-339). The other Islamic city governments had been formed in Hausa and Euroba or Benin in West Africa. These governments gradually developed Islam and Arabic languages (Mo'tasem 1991:Vol. 10, 391). With the beginning of colonialism in different parts of Africa and the collapse of Islamic governments, the spreading of Islam didn't stop there but Islamic Institutes were built and Islam continued (Bari et al. 1971:249).

\section{Conclusion}

Islamic conquest had been done as part of Islamic Jihad for the development of Islam in the 7th and 8th centuries, but it would not be true that Islam grew through violence everywhere. Studying the spreading of Islam in Eastern, Central and Western Africa has shown that Islam was introduced by immigrants, who were traders and religious scholars, and mostly Sufis, among the diverse tribes such as Berber, Tuariq, Zang, Hausa and Bulala. With different opinions in these vast areas, the chiefs of tribes, such as Fonj, Zoghavah and Songhay, adopted Islam and formed Islamic governments among their tribes. The development of Islam and formation of Islamic governments occurred without force and violence and Islam was introduced to native inhabitants, which found some connection with Islam and their local customs. Although this process had been done slowly, its effects persisted and the spreading of Islam continued in these areas even with the arrival of colonialism. Therefore, if Islam was introduced via moderate tolerance and bilateral dialogue between Muslims and non-Muslims, as it occurred in Eastern, Central and Western Africa, its effects would continue even if Islamic governments collapse in these regions because the Muslims are the majority in those regions. There are some challenges for researchers to consider: why is there not a favourable and peaceful existence in these African countries that are regarded as Islamic countries? Is Islam an inefficient religion or is the real Islam not being introduced? Does Islam respond to all needs of humans? Researchers will have to address these questions.

\section{Acknowledgements Competing interests}

The authors declare that they have no competing interests with regard to the writing of this article. 


\section{Authors' contributions}

E.B. conceptualised the article and conducted initial research. M.S. edited the article, analysed the data and adjudicated where necessary. Both authors reviewed and approved the final manuscript.

\section{References}

Ali, B.H.A.A., 1961, Makhtutah Katib al Shunah fi Tarikh al Saltanah va Edarah Egypt researched by S. Basili \& M. Ziyada, Vezarah al Theqafah, Cairo.

Asante, M.K., 2007, The history of Africa, Routledge, New York.

Bakri, A.U., 2002 'Kitab al al Masalik wa-I-Mamalik', in Van leeuwen \& Ferre, Tunisia (eds.), vol. 1, pp. 320-325.

Bari, A., Fazel, M. \& Keridiyyah, S.I., 1971, Al Muslims fi West Africa, Tarikh va Hedharh Dar al Kotob al Elmiyyah, Beirut.

Bruce, J., 1790, Travels to discover the sources of the Nile in the years 1768 , $1769,1770,1771,1772,1773$, Paternoster, England.

Bruder, E., 2008, The black Jews of Africa: History, religion, identity, Oxford University Press, Oxford.

Collelo, T., 1988, Chad: A country study, Library of Congress, Washington, DC.

Fazli, J.M., 1921, Ketab al Tabaqat fi Khosus al Owliya va al Salehin va al Olama va a Shoara fi al Sudan, Aljazirah fi al Teba'ah, Khartum.

Fituri, A.M, 1998, Derasat fi Tarikh Sharq Efriqiya va Jonub Sahara, Benghazi, Sherkah al Matbua't lel Tozi'e va al Nashr, Manthurat University of qaz Yunes.

Hafiz, S., 1982, Sora' al Qowa Hawl al Qarn al Efriqi, al Majlis al Vatani lel Theqafah va al Fonun va al Adab, Kuwait.

Hartman, R., 2004, Al Habashah va al Manateq al Sahelliyyah al Sharqiyyah al Okhra men Efriqiya, al Majma' al Theqafi, Abu Dhabi.

Hasan, F.Y., 2003, Moqaddama fi Tarikh al Mamalik al Islamiyya fi Sudan Al Sharqi, 1450-1821, Dar al Sudaniyyah lel Kotob, Khartoum.

Hiskett, M., 1994, The course of Islam in Africa, Edinburgh University Press, Edinburgh. Holt, P.M. \& Daly, M.W., 2000, A history of Sudan: From the coming of Islam to the present day, Routledge, London.
Ibrahim, S.M., 2000, Dowlat al Zanjbar al Hadithah fi Ahd al Soltan Saeed ibn Soltan, Center of Jehad al libiyyin, Benghazi.

Jamal, S.H., 2008, Tarikh Sudan Vadi al Nile, Hedharatohu va Alaqatohu be Misr Men Aqdam al Osur ela al Vaqt al Hadher, Cairo.

Khuli, M.A., 2011, Al Arab va Dorahom al Hedhari fi Sharq Efriqiya, Matabah al Theqafah al Diniyyah, Cairo.

Maqrizi, A.A, 2002, Al Mawaez va al E'tebar be Zekr al Khetat va al Athar, I.F. Seyyed (ed.), vol. 1, pp. 543, al Forqan lel Torath al Islami, London.

Mas'udi, A., 1970, Moruj al Dhahab va Ma'aden al Johar, transl. B. de Meynard \& C.A. Casimir, Imperial, Paris.

Metz, C.H., 1992, Sudan: A country study, Library of Congress, Washington, DC.

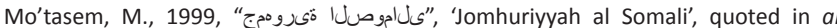
Mosu'ah al Geographic le al A'lam al Islami, vol. 10, pp. 391, Vezarah al Ta'lim al $A^{\prime} l i$, Riyadh.

Mohanna, A., 1954, al Somali Bayn al Hayatayn, Dar al Hila, Riyadh.

Mohy al Din Mohammad, S., 1995, Sheykh Ajib va al Dowlah al Islamiyya fi Sennar, Maktabatah Al Helal, Beirut.

Nequla, Z., 2002, Efriqiyyat Derasat fi al Maghreb al Arabi, al Ahliyya, Beirut.

Night, S., 2012, Mogadishu, Somalia, Earth Eyes Travel Guides.

Nuri, A.Q., 1985, Tarikh Islam fi Efriqiya Jonub Sahara, Vezarah al Ta'lim va al A'li va a bahth al Elmi, Mussel.

Page, F.W., 2001, Encyclopedia of African history and culture: From conquest to colonization (1500-1850), Facts on File Inc. New York.

Peek, P.M., 1991, African divination systems: Ways of knowing, IU Press, IN.

Sa'd, I., 1989. Tabaqat al Kobra, Dar Sader, Beirut.

Sari al Din, A.A., 1997, al Sudan va al Nile Bayn al Metrafah al Enfesal va al Sendan a Israeli, Dar al 'Afaq al jadidah, Beirut.

Shater Basili, A.J., 1972, Tarikh va Hedharat al Sudan al sharqi va al Awsat from 7-19 Centuries, Al Heyat al Misriyyah lel Kitab, Cairo.

Sidahmed, A.S. \& Sidahmed, A., 2005, Sudan, Routledge, London.

Trimingham, J.S., 1952, Islam in Ethiopia, Oxford University Press, London.

Trimingham, J.S., 1965, Islam in the Sudan, Frank Cass and Co. Ltd, London.

Yunes, M.A., 1962, Al Somali Vatana va She'ba, Dar al Nahzat al Arabiyyah, Cairo. 